\title{
Pengaruh Temperatur Sintesis Terhadap Karakteristik Polidimethylsiloxane
}

\author{
Siti Nur Kholifiyah", Anisa Tri Rahayu, Wiendartun, Waslaluddin \\ Prodi Fisika, Fakultas Pendidikan Matematika dan Ilmu Pengetahuan Alam \\ Universitas Pendidikan Indonesia
}

*Corresponding Author: snurkholifiyah@gmail.com

\begin{abstract}
ABSTRAK
Dalam bidang medis, material polydimethylsiloxane (PDMS) memiliki peranan yang sangat penting. Dikarenakan sifat polydimethylsiloxane yang biokompatibilitas unggul, toksisitas rendah, oksidatif dan temperatur stabil. Selain itu PDMS juga bersifat tidak beracun sehingga aman digunakan untuk tubuh manusia. Salah satu penggunaannya adalah sebagai cairan pengganti vitreous humor. Untuk itu, diperlukan PDMS yang memiliki karakteristik menyerupai karakteristik vitreous humor. Pada penelitian ini, PDMS disintesis menggunakan teknik ring-opening polymerization. Temperatur sintesisnya divariasikan sebesar $140{ }^{\circ} \mathrm{C}, 150$ ${ }^{0} \mathrm{C}$, dan $170{ }^{0} \mathrm{C}$. PDMS ynag terbentuk dikarakterisasi menggunakan viskometer, refraktometer, tensiometer dan FTIR. Nilai viskositas masing -masing PDMS terukur sebesar 0,088 Pa.s, 0,332 Pa.s, dan 1,210 Pa.s. Untuk nilai indeks bias masing-masing PDMS diperoleh sebesar 1,4001, 1,4014, dan 1,4032. Adapun nilai tegangan permukaan masing-masing PDMS yang terukur adalah sebesar 21,5 mN/m, 21,8 mN/m, dan 22,0 $\mathrm{mN} / \mathrm{m}$. Ketiga data PDMS memiliki gugus fungsi serapan yang sama dengan PDMS standar, yaitu terdapat getaran deformasi $\mathrm{CH}_{3}$ aromatik, ikatan $\mathrm{Si}-\mathrm{O}-\mathrm{Si}, \mathrm{Si}-\mathrm{CH}_{3}, \mathrm{Si}-\mathrm{CH}_{3}$ dan kelompok metilen.

Kata kunci : Temperature, Polydimethylsiloxane, Teknik Ring Opening Polymerization
\end{abstract}




\begin{abstract}
In the medical field, polydimethylsiloxane (PDMS) material has very important importance. Due to the superior biocompatibility, low toxicity, oxidative and temperature stable properties of polydimethylsiloxane. In addition, PDMS is also non-toxic so it is safe to use for the human body. One of its uses is as a vitreous fluid. For that, a PDMS is needed which contains humor. In this study, PDMS was synthesized using ring-opening polymerization technique. The synthesis temperature was varied by $1400 \mathrm{C}, 1500 \mathrm{C}$, and $1700 \mathrm{C}$. The PDMS formed was characterized using a viscometer, refractometer, tensiometer and FTIR. The viscosity values of each measured PDMS were 0.088 Pa.s, 0.332 Pa.s, and 1,210 Pa.s. For the refractive index value of each PDMS, it was obtained 1.4001, 1.4014, and 1.4032. The measured surface tension values of each PDMS were $21.5 \mathrm{mN} / \mathrm{m}, 21.8 \mathrm{mN} / \mathrm{m}$, and $22.0 \mathrm{mN} / \mathrm{m}$. The third data PDMS has the same absorption functional group as the PDMS standard, namely there is a deformation vibration of $\mathrm{CH} 3$ aromatic, Si-O-Si bonds, $\mathrm{Si}-\mathrm{CH} 3$, $\mathrm{Si}-\mathrm{CH} 3$ and methylene groups.
\end{abstract}

Keywords: Temperature, Polydimethylsiloxane, Ring Opening Polymerization Technique

\section{Pendahuluan}

Dalam pembuatan perangkat biomedis, material polydimethylsiloxane (PDMS) memiliki peranan yang sangat penting. Polydimethylsiloxane (PDMS) merupakan salah satu jenis polimer sintetik yang memiliki sifat berpori [1]. Beberapa keunggulan yang dimiliki polydimethylsiloxane, diantaranya adalah biokompatibilitas yang unggul, toksisitas rendah, oksidatif dan temperatur yang stabil [2]. Selain itu, polydimethylsiloxane memiliki sifat transparansi dan fleksibilitas [3].
Salah satu penggunaan PDMS di bidang medis adalah sebagai cairan pengganti vitreous humor. Vitreous humor adalah gel avaskuler yang terdiri dari fibril kolagen yang terletak diantara lensa dan retina. Penggantian cairan vitreous humor diperlukan untuk mengobati beberapa penyakit, seperti ablasi mata dan retinopati diabetik [4]. Ablasi mata merupakan peristiwa pelepasan vitreous humor akibat permukaan retina yang bersentuhan langsung dengan vitreous. Adanya pelepasan vitreous atau ablasi dapat menyebabkan kebutaan [5]. 
Polydimethylsiloxane dipilih karena memiliki sifat tidak berfluoresensi dan tidak beracun sehingga aman untuk tubuh [6]. Selain itu, polydimethylsiloxane juga memiliki risiko lebih rendah mengalami emulsifikasi [7].

Polimerisasi merupakan nama lain dari sintesis polimer, proses dimana monomer monomer dihubungkan untuk menghasilkan rantai panjang yang terdiri dari unit berulang. Dalam polimerisasi terdapat beberapa faktor yang mempengaruhinya, diantaranya konsentrasi katalis, bahan yang digunakan dan suhu [8] Terdapat berbagai macam teknik dalam mensintesis polydimethylsiloxane, teknik ring-opening polymerization (ROP) merupakan salah satunya. Teknik ROP menghasilkan kontrol atas parameter monomer dari polimer lebih besar. Selain itu, penerapannya memungkinkan adanya kontrol atas urutan penyisipan monomer ke dalam rantai polimer berdasarkan stereokimia [9]. Teknik ROP sendiri merupakan teknik yang digunakan untuk memutuskan rantai ikatan siklik suatu senyawa [10]. Pemutusan ikatan ini dilakukan untuk memudahkan senyawa siklik bereaksi dengan senyawa lain [11]. Teknik ini juga digunakan untuk menghasilkan poli dengan berat monomer tinggi [12].

Dalam penelitian ini, untuk mensintesis PDMS teknik ring-opening polymerization (ROP) digunakan untuk memutuskan rantai siklik dari D4. Pemutusan rantai monomer ini dilakukan supaya monomer D4 dapat cepat bereaksi dengan MM dalam membentuk PDMS [13]. PDMS yang terbentuk hasil sintesis akan menunjukkan sifat transparan dan kental. Untuk mengetahui karakteristik PDMS tersebut, dapat dilakukan karakterisasi menggunakan alat ukur yang sesuai. Dalam penelitian ini, PDMS disintesis menggunakan teknik ring-opening polymerization, kemudian dikarakterisasi untuk dimanfaatkan sebagai cairan pengganti vitreous humor.

\section{Metode}

\section{2.a. Sintesis}

Dalam mensintesis PDMS, bahan yang digunakan yaitu, Octamethylcyclotetrasiloxane (D4), dan Hexamethyldisiloxane (MM) sebagai monomer, serta temperatur sebagai inisiator.

D4 dicampurkan dengan MM dengan perbandingan $26: 10$ [14], kemudian diaduk menggunakan magnetic stirrer dengan temperatur 140 ${ }^{0}$ C. Ketika D4 dan MM diaduk, larutan $\mathrm{KOH}$ ditambahkan secara perlahan sebanyak 0,06 ml. Pengadukan larutan dilakukan selama 40 menit sampai terbentuk gel PDMS. 
Gel PDMS yang terbentuk kemudian dipurifikasi. Gel dilarutkan menggunakan kloroform dengan perbandingan volume gel dan kloroform adalah 1:1. Campuran gel dan kloroform kemudian diaduk. Pengadukan ini dilakukan selama 10 menit menggunakan magnetic stirrer. Setelah itu, mili- $q$ water ditambahkan ke dalam larutan dengan perbandingan volume larutan dan mili-q water yaitu 2:1. Kemudian larutan didiamkan sampai terbentuk dua fasa yang terdiri dari gel dan air. Air yang dihasilkan dibuang dan di cek pHnya. Tahap purifikasi dilakukan sampai menghasilkan $\mathrm{pH}$ bernilai 7 atau netral. Tahap ini dilakukan untuk menghilangkan kandungan $\mathrm{KOH}$ sisa reaksi dalam gel. Langkah terkahir dalam mensintesis PDMS, yaitu pengadukan kembali larutan menggunakan magnetic stirrer pada temperatur $40{ }^{0} \mathrm{C}$ sampai kloroform dalam larutan hilang.

\section{2.b. Karakterisasi}

PDMS hasil sintesis dikarakterisasi menggunakan beberapa alat ukur, yaitu refraktometer, viskometer, tensiometer, dan FTIR. Refraktometer AS ONE I-500 (Brix $0 \sim 90 \%$ ) digunakan untuk mengukur karakteristik indeks bias PDMS. Viskometer model VM-10AMH digunakan untuk mengukur karakteristik viskositas PDMS. Tensiometer digunakan untuk mengukur karakteristik tegangan permukaan PDMS. Dan FTIR digunakan untuk melihat gugus fungsi PDMS.

\section{Hasil dan Pembahasan}

Sintesis PDMS dengan metode polimerisasi yang digunakan, yaitu teknik ring-opening polymerization (ROP) dan temperatur sintesisnya divariasikan telah dilakukan. Terdapat tiga sampel PDMS yang berhasil disintesis dengan variasi suhu sintesisnya, yaitu $140{ }^{\circ} \mathrm{C}, 150{ }^{\circ} \mathrm{C}$, dan ${ }^{\circ} \mathrm{C}$. Kemudian dilakukan karakterisasi untuk mengetahui pengaruh temperatur sintesis yang divariasikan terhadap beberapa karakteristik PDMS. Karakateristik PDMS yang diukur, diantaranya viskositas, indeks bias, tegangan permukaan, dan gugus fungsi. Adapun hasil yang diperoleh dari hasi karakterisasi adalah sebagai berikut.

\section{3.a. Viskositas}

Hasil pengukuran viskositas PDMS dengan konsentrasi $\mathrm{KOH}$ 0,75 $\mathrm{M}$ dan temperatur sintesisnya divariasikan ditunjukkan oleh tabel 1.

Tabel 1. Nilai viskositas PDMS dengan temperatur sintesis divariasikan

\begin{tabular}{ccc}
\hline Sampel & $\begin{array}{c}\text { Temperatur } \\
\text { Sintesis }\left({ }^{\circ} \mathrm{C}\right)\end{array}$ & $\begin{array}{c}\text { Viskositas } \\
(\mathrm{mPa} . \mathrm{s})\end{array}$ \\
\hline 1 & 140 & 87,7 \\
2 & 150 & 332,0 \\
3 & 170 & 1210,0 \\
\hline
\end{tabular}

Tabel 1. menunjukkan viskositas yang terukur pada PDMS dengan temperatur sintesis yang divariasikan mengalami perubahan. Perubahan ini membuktikan 
adanya pengaruh temperatur sintesis terhadap karakteristik PDMS berupa viskositas. Hal ini disebabkan karena temperatur mempengaruhi kecepatan reaksi [5]. Penelitian sebelumnya menjelaskan bahwa PDMS dengan viskositas rendah memiliki berat monomer rendah [16]. PDMS yang memiliki berat monomer rendah lebih rentan terhadap emulsifikasi [17]. Dari ketiga data yang dihasilkan, PDMS dengan temperatur $170{ }^{0} \mathrm{C}$ memiliki nilai viskositas yang lebih tinggi. Nilai ini menunjukkan bahwa pada temperatur $170 \quad{ }^{\circ} \mathrm{C}$ berat monomer PDMS lebih tinggi dibandingkan kedua sampel PDMS lainnya.

Untuk itu, PDMS dengan temperatur $170{ }^{0} \mathrm{C}$ memiliki jangka waktu yang panjang dikarenakan terjadinya emulsifikasi lebih lambat. PDMS dengan temperatur $170{ }^{\circ} \mathrm{C}$ juga adalah PDMS yang nilai viskositasnya paling mendekati nilai viskositas PDMS komersial $1300 \mathrm{cSt}$, yaitu sebesar 1,08 Pas [14].

\section{3.b. Indeks Bias}

Berdasarkan pengukuran indeks bias PDMS yang telah dilakukan menggunakan refraktometer, nilai indeks bias PDMS yang terukur terdapat pada tabel 2 .
Tabel 2. Nilai indeks bias PDMS dengan temperatur sintesis divariasikan

\begin{tabular}{ccc}
\hline Sampel & Temperatur & Indeks Bias \\
\hline 1 & 140 & 1,40006 \\
2 & 150 & 1,40142 \\
3 & 170 & 1,40320 \\
\hline
\end{tabular}

Tabel 2. menunjukkan adanya perubahan pada indeks bias PDMS yang terukur. Hasil ini menunjukkan bahwa temperatur sintesis yang divariasikan memengaruhi indeks bias PDMS. Jika dibandingkan nilai indeks bias pada vitreous humor yang berada pada kisaran 1,3345 hingga 1,3348 dengan nilai indeks bias sampel PDMS dalam penelitian ini, nilai indeks bias sampel PDMS-lah yang lebih tinggi. Perbedaan ini dapat mengakibatkan miopia pada pasien bedah vitreoretinal [18]. Walaupun demikian, nilai indeks bias PDMS dengan temperatur $170{ }^{\circ} \mathrm{C}$ mendekati nilai indeks bias yang dihasilkan oleh jurnal lain, yaitu sebesar 1,4040 [13].

\section{3.c. Tegangan Permukaan}

Tabel 3. menunjukkan adanya pengaruh temperatur terhadap tegangan permukaan PDMS yang telah diukur menggunakan tensiometer. Tegangan permukaan bertanggung jawab atas bentuk tetesan cairan karena menggambarkan kekuatan yang cenderung menjaga keseluruhan gelembung. 
menjaga keseluruhan gelembung. Tegangan permukaan PDMS yang tinggi merupakan alasan dimana PDMS dengan viskositas yang lebih tinggi dianggap lebih jarang mengemulsi dibandingkan PDMS dengan viskositas yang lebih rendah (Barca dkk., 2014). Sampel satu, yaitu PDMS dengan temperatur sintesisnya $140 \quad{ }^{\circ} \mathrm{C}$ mendekati nilai tegangan permukaan PDMS komersial tipe $1300 \mathrm{cSt}$ sebesar $20 \mathrm{mN} / \mathrm{m}$ [14].

Tabel 3. Nilai tegangan permukaan PDMS dengan temperatur sintesis divariasikan

\begin{tabular}{ccc}
\hline Sampel & $\begin{array}{c}\text { Temperatur } \\
\text { Sintesis }\left({ }^{\circ} \mathrm{C}\right)\end{array}$ & $\begin{array}{c}\text { Tegangan } \\
\text { Permukaan } \\
(\mathrm{mN} / \mathrm{m})\end{array}$ \\
\hline 1 & 140 & 21,5 \\
2 & 150 & 21,8 \\
3 & 170 & 22,0 \\
\hline
\end{tabular}

Untuk menghindari terjadinya emulsifikasi, faktor penurunan tegangan permukaan ketika PDMS disuntikkan ke mata diusahakan tidak ada [19].

\section{3.d. Gugus Fungsi}

Hasil karakterisasi sampel PDMS dan PDMS komersil tipe $1300 \mathrm{cSt}$ menggunakan FTIR ditunjukkan oleh gambar 1 .

Hasil FTIR PDMS komersil pada gambar 1(a) menunjukkan adanya beberapa puncak yang terbentuk, diantaranya pada $2961,4 \mathrm{~cm}-1,2905,1 \mathrm{~cm}-$ 1, 1412,0 cm-1, 1262,7 cm-1, 1045,6 cm1, 812,2 cm-1, dan 702,7 cm-1. Dari data tersebut, dapat diamati bahwa ada puncak penyerapan yang kuat pada panjang gelombang 1262,7 cm-1 dan 812,2 cm-1. Kedua puncak tersebut menunjukkan adanya ikatan Si-CH3 pada PDMS. Puncak kuat lainnya, yaitu 1045,6 cm-1 menunjukkan adanya getaran peregangan Si-O-Si pada PDMS komersil. Untuk puncak penyerapan kuat lainnya pada PDMS diidentifikasi pada 1412,0 cm-1. Pucak ini sesuai dengan deformasi asimetris metilen (CH3) dari Si-CH3. Sementara itu, untuk puncak serapan 2961,4 cm-1 dan 2905,1 cm-1 disebabkan oleh adanya kelompok metilen dari PDMS. Puncak terakhir yang memiliki penyerapan kuat teridentifikasi pada panjang gelombang $702,7 \mathrm{~cm}-1$. Puncak ini sesuai dengan getaran deformasi $\mathrm{CH} 3$ aromatik.

Pada Gambar 1, ketiga sampel PDMS memiliki gugus fungsi yang sama dengan PDMS komersial, yaitu ikatan Si-O-Si, Si$\mathrm{CH}_{3}, \mathrm{Si}-\mathrm{CH}_{3}$ dan kelompok metilen. Tetapi titik puncak ketiga sampel PDMS yang dihasilkan dari karakterisasi FTIR berbeda sedikit dengan titik puncak PDMS komersil. Puncak-puncak yang teridentifikasi pada PDMS dengan temperatur $140{ }^{\circ} \mathrm{C}$, yaitu pada panjang gelombang 2964,0 cm-1, 2906,7 cm-1, $1412,2 \mathrm{~cm}-1,1261,1 \mathrm{~cm}-1,1075,0 \mathrm{~cm}-1$, $805,5 \mathrm{~cm}-1$, dan $697,8 \mathrm{~cm}-1$. Untuk sampel PDMS dengan temperatur sintesis 


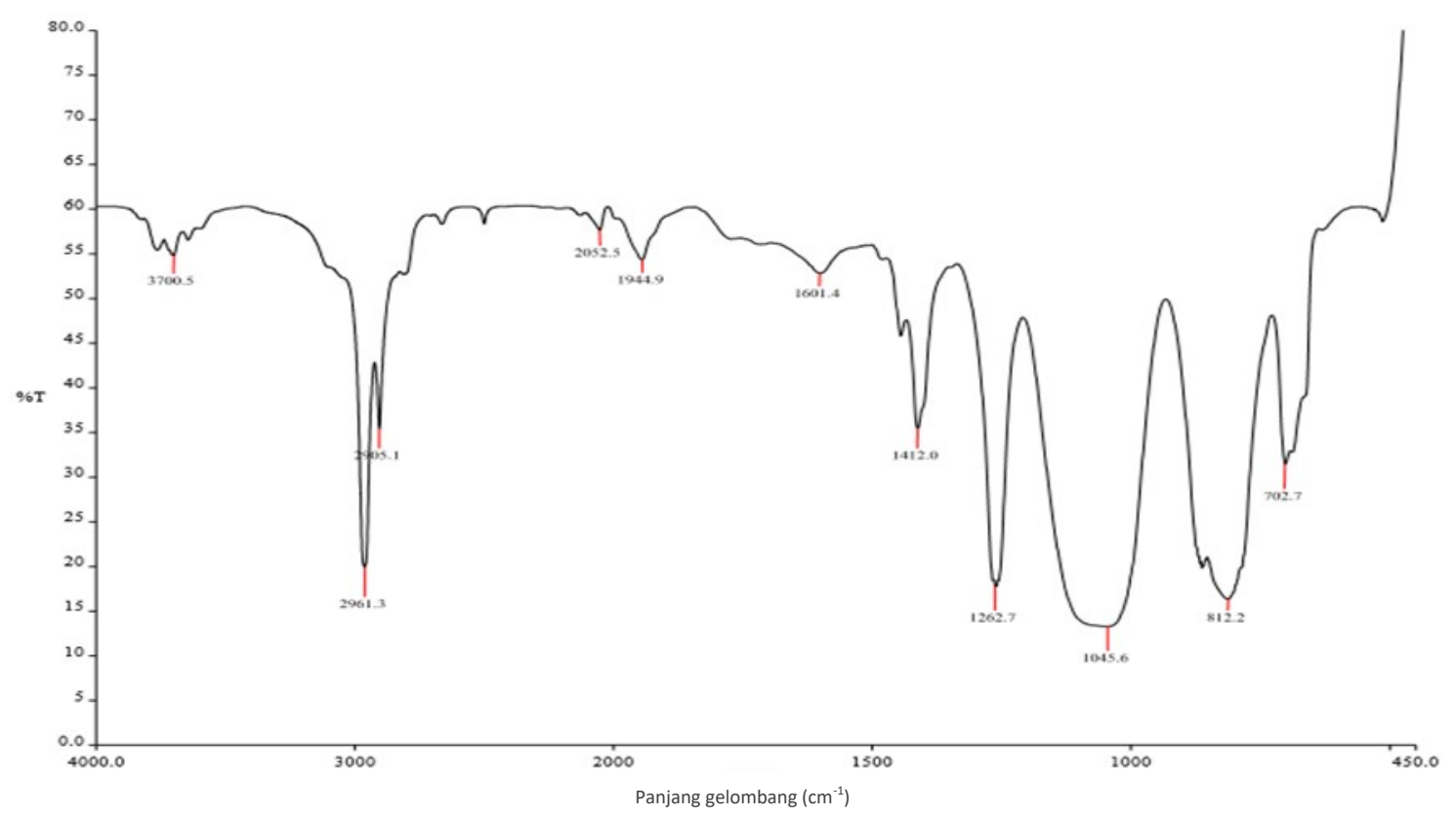

(a)

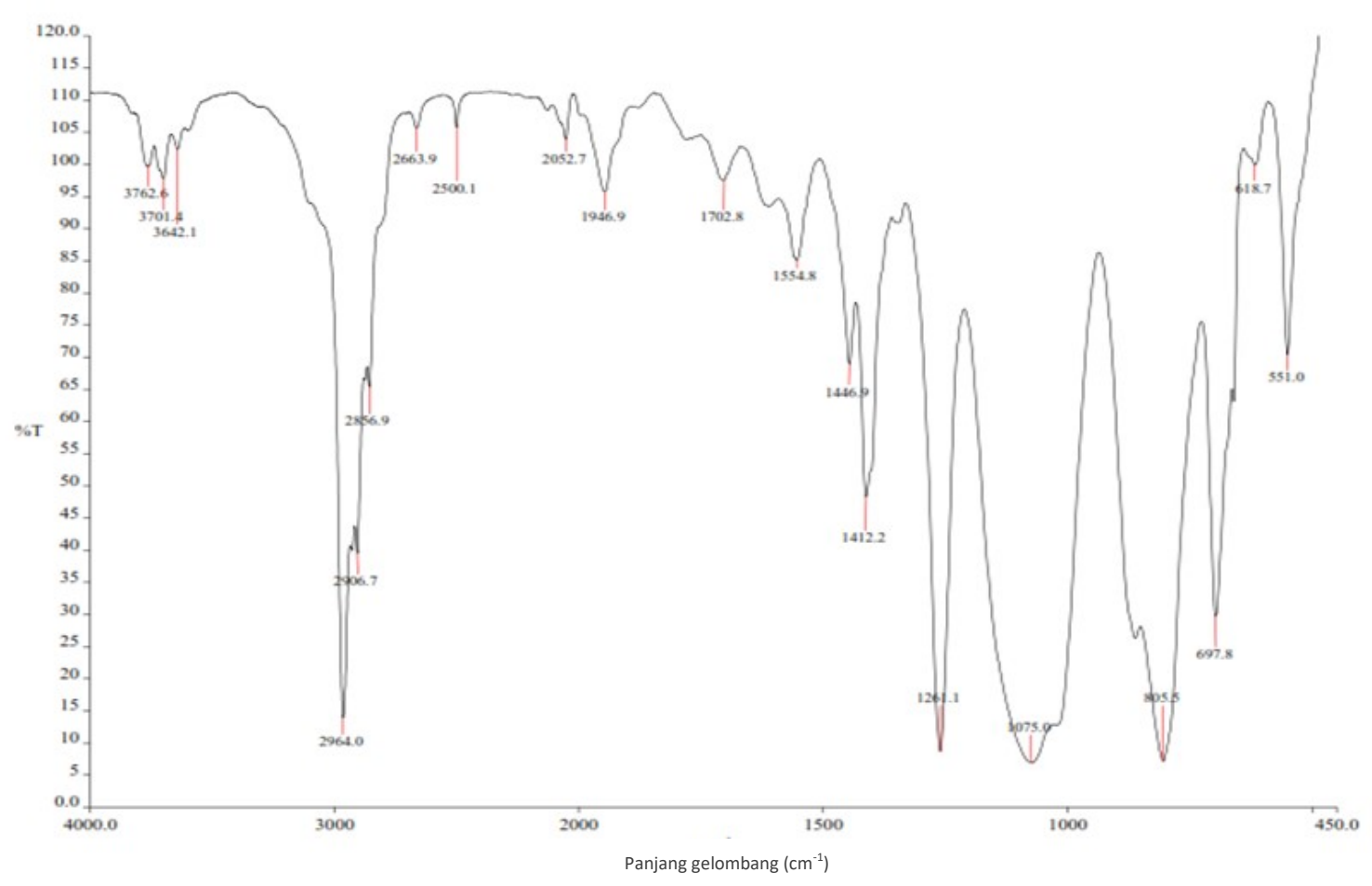

(b) 
Wahana Fisika, 5(2), 2020. 113 - 124

http://ejournal.upi.edu/index.php/wafi

e-ISSN : 2594-1989 https://doi.org/10.17509/wafi.v5i2.26447

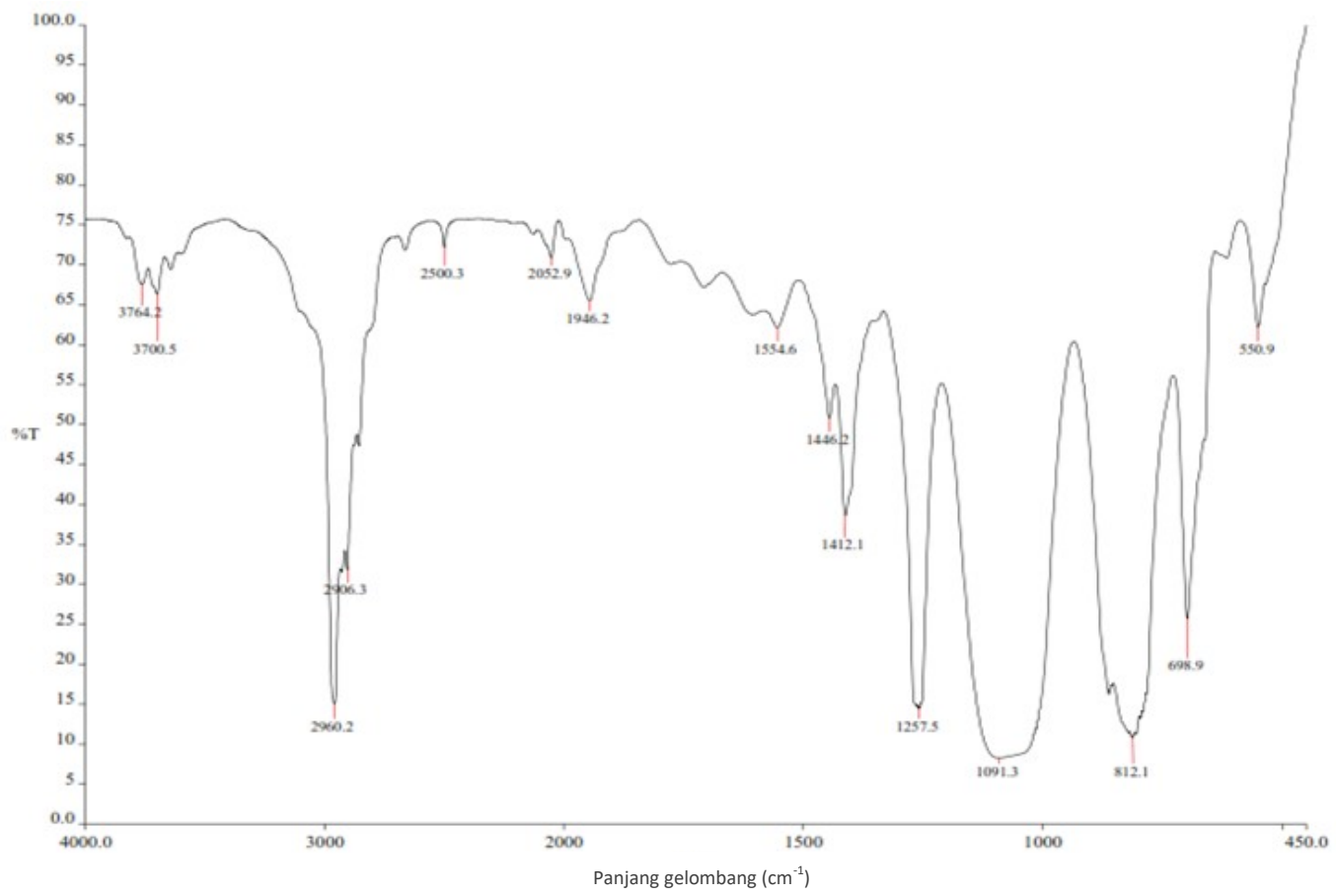

(c)

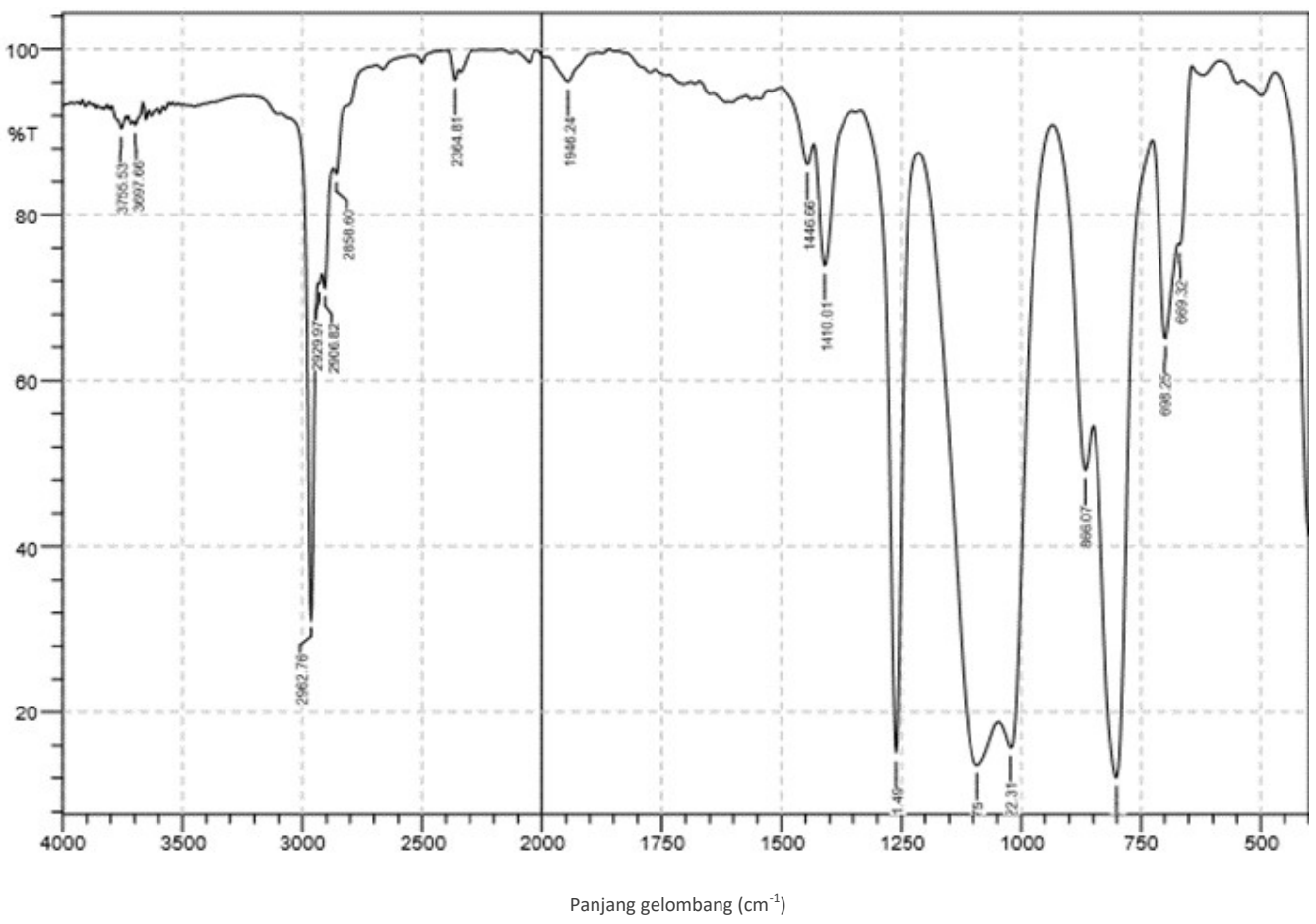

(d)

Gambar 1. Hasil FTIR PDMS (a) Komersil $1300 \mathrm{cSt}$, (b) sampel satu T $=140{ }^{\circ} \mathrm{C}$, (c) sampel dua $\mathrm{T}=150{ }^{\circ} \mathrm{C}$, dan (d) pada $\mathrm{T}=170{ }^{\circ} \mathrm{C}$ 
150 0C, puncak penyerapannya ada pada panjang gelombang 2960,2 cm-1, 2906,3 $\mathrm{cm}-1,1412,1 \mathrm{~cm}-1,1257,5 \mathrm{~cm}-1,1091,3$ cm-1, 812,1 cm-1, dan 698,9 cm-1. Dan pada sampel tiga PDMS yaitu 170 0C, puncak penyerapan yang teridentifikasi, diantaranya pada panjang gelombang 2962,76 cm-1, 2929,97 cm-1, 2906,82 cm1, 1410,01 cm-1, 1261,49 cm-1, 1091,75 cm-1, 1022,31 cm-1, 866,07 cm-1, 800,49 cm-1, dan 698,25 cm-1.

Adapun persamaan ikatan yang terbentuk antara ketiga sampel PDMS dengan PDMS komersil yang dijelaskan dengan PDMS komersil yang dijelaskan diatas ditunjukkan pada tabel 4. Selain itu, terdapat juga perbedaan hasil karakterisasi ketiga sampel PDMS dengan PDMS komersil. Perbedaan tersebut terletak pada puncak yang terbentuk. Puncak yang dihasilkan pada ketiga sampel PDMS, tidak hanya yang terdapat pada tabel tetapi juga terdapat puncak lainnya meskipun tingkat penyerapannya lebih rendah dari puncak yang di tabel. Puncak ini berasal dari bahan sisa sintesis yang tidak terikat atau terperangkap dalam PDMS [20].

Tabel 1. Perbandingan Gugus Fungsi PDMS komersil 1300cSt dengan PDMS yang temperaturnya divariasikan

\begin{tabular}{|c|c|c|c|c|}
\hline \multirow{2}{*}{ Pita } & \multicolumn{4}{|c|}{ Panjang Gelombang } \\
\hline & Komersil & Pada $\mathrm{T}=140{ }^{\circ} \mathrm{C}$ & Pada $\mathrm{T}=150{ }^{\circ} \mathrm{C}$ & Pada $\mathrm{T}=170{ }^{\circ} \mathrm{C}$ \\
\hline $\begin{array}{l}\text { Getaran deforma- } \\
\text { si } \mathrm{CH}_{3} \text { aromatik }\end{array}$ & $702,7 \mathrm{~cm}^{-1}$ & $697,8 \mathrm{~cm}^{-1}$ & $698,9 \mathrm{~cm}^{-1}$ & $\begin{array}{c}866,07 \mathrm{~cm}^{-1} \text { dan } \\
698,9 \mathrm{~cm}^{-1}\end{array}$ \\
\hline $\mathrm{Si}-\mathrm{O}-\mathrm{Si}$ & $1045,6 \mathrm{~cm}^{-1}$ & $1075,0 \mathrm{~cm}^{-1}$ & $1091,3 \mathrm{~cm}^{-1}$ & $\begin{array}{c}1091,75 \mathrm{~cm}^{-1} \mathrm{dan} \\
1022,31 \mathrm{~cm}^{-1}\end{array}$ \\
\hline $\mathrm{Si}-\mathrm{CH}_{3}$ & $\begin{array}{c}1262,7 \mathrm{~cm}^{-1} \\
\text { dan } 812,2 \mathrm{~cm}^{-}\end{array}$ & $\begin{array}{c}1261,1 \mathrm{~cm}^{-1} \text { dan } \\
805,5 \mathrm{~cm}^{-1}\end{array}$ & $\begin{array}{c}1257,5 \mathrm{~cm}^{-1} \text { dan } \\
812,1 \mathrm{~cm}^{-1}\end{array}$ & $\begin{array}{c}1261,49 \mathrm{~cm}^{-1} \text { dan } \\
800,49 \mathrm{~cm}^{-1}\end{array}$ \\
\hline $\begin{array}{c}\text { Deformasi as- } \\
\text { imetris metilen } \\
\left(\mathrm{CH}_{3}\right) \text { dari Si- } \\
\mathrm{CH}_{3}\end{array}$ & $1412,0 \mathrm{~cm}^{-1}$ & $1412,2 \mathrm{~cm}^{-1}$ & $1412,1 \mathrm{~cm}^{-1}$ & $1410,01 \mathrm{~cm}^{-1}$ \\
\hline $\begin{array}{c}\text { Kelompok } \\
\text { Metilen }\left(\mathrm{CH}_{3}\right)\end{array}$ & $\begin{array}{c}2961,4 \mathrm{~cm}^{-1} \\
\text { dan } 2905,1 \\
\mathrm{~cm}^{-1}\end{array}$ & $\begin{array}{c}2964,0 \mathrm{~cm}-1 \text { dan } \\
2906,7 \mathrm{~cm}^{-1}\end{array}$ & $\begin{array}{c}2960,2 \mathrm{~cm}^{-1} \text { dan } \\
2906,3 \mathrm{~cm}^{-1}\end{array}$ & $\begin{array}{c}2962,76 \mathrm{~cm}^{-1} \\
2929,97 \mathrm{~cm}^{-1} \mathrm{dan} \\
2906,82 \mathrm{~cm}^{-1}\end{array}$ \\
\hline
\end{tabular}




\section{Simpulan}

Berdasarkan hasil penelitian, sintesis PDMS dengan teknik ring-opening polymerization dan temperatur sintesisnya diubah-ubah telah terbentuk. Sintesis dilakukan dengan D4 dan MM sebagai bahannya, larutan $\mathrm{KOH}$ sebagai katalis dengan konsentrasi $0,75 \quad \mathrm{M}$, dan temperatur sintesisnya, yaitu $140{ }^{\circ} \mathrm{C}, 150$ ${ }^{0} \mathrm{C}$, dan $170{ }^{\circ} \mathrm{C}$.

Hasil karakterisasi ketiga sampel PDMS menunjukkan adanya pengaruh temperatur terhadap karakteristik PDMS. Ketiga sampel PDMS masing-masing memiliki nilai viskositas sebesar 0,088 Pa.s, 0,332 Pa.s, dan 1,210 Pa.s. Sampel PDMS dengan temperatur sintesis sebesar $170{ }^{0} \mathrm{C}$ mendekati nilai viskositas PDMS komersil 1300 cSt. Hasil pengukuran refraktometer untuk sampel PDMS dengan temperatur sintesisnya $140{ }^{\circ} \mathrm{C}$, yaitu 1,4001. Sedangkan untuk sampel PDMS dengan temperatur $150{ }^{\circ} \mathrm{C}$, dan $170{ }^{0} \mathrm{C}$, nilai indeks biasnya adalah 1,4014, dan 1,4032. Adapun nilai tegangan permukaan sampel PDMS yang memiliki nilai viskositas 0,088 Pa.s, yaitu sebesar 1,4001. Untuk sampel dengan viskositas 0,332 Pa.s memiliki nilai tegangan permukaan sebesar 1,4014 dan PDMS dengan viskositas 1,210 Pa.s, sebesar 1,4032. Ketiga sampel PDMS memiliki ikatan fungsi yang sama dengan PDMS komersil, yaitu ikatan Si-O-Si, Si$\mathrm{CH}_{3}, \mathrm{Si}_{-} \mathrm{CH}_{3}$ dan kelompok metilen.

\section{Ucapan Terimakasih}

Ucapan terimakasih ditujukan untuk seluruh pihak yang berkontribusi dalam penelitian ini. Pihak yang telah mendanai penelitian ini adalah Kemenristek Dikti untuk Penelitian Dasar UnggulanPerguruan Tinggi (PDUPT) dengan No.2019 No.6/E/ KPT/2019. Penelitian ini juga didukung Lembaga Penelitian dan Pengabdian Masyarakat UPI No.171A/ UN40.D/ PP/2019.

\section{Referensi}

1. Toepke, M. W., \& Beebe, D. J. (2006). PDMS absorption of small molecules and consequences in microfluidic applications. Lab on $a$ Chip, 6(12), 1484-1486. doi: https:// doi.org/10.1039/b612140c

2. Yamamoto, T., Nojima, T., \& Fujii, T. (2002). PDMS-glass hybrid microreactor array with embedded temperature control device. Application to cell-free protein synthesis. Lab on a Chip, 2(4), 197-202. doi: https://doi.org/10.1039/b205010b

3. Niu, X., Peng, S., Liu, L., Wen, W., \& Sheng, P. (2007). Characterizing and patterning of PDMS-based conducting composites. Advanced Materials, 19(18), 2682-2686. doi: https://doi.org/10.1002/ adma.200602515

4. Raia, Nicole R, Di Jia, Chiara E. G., Murugappan M., \& David L. K. 
(2019). "Characterization of silkhyaluronic acid composite hydrogels towards vitreous humor substitutes". Biomaterials. doi: https:// doi.org/10.1016/ j.biomaterials.2019.119729

5. Silue, Tjerignimin A., Saugandhika M., \& Nathalia P. (2016). "Electrochemical 41 Characterization of Vitreous Humor". Procedia Technology, 27, 301 303. doi: https://doi.org/10.1016/ j.protcy.2017.04.124

6. Mata, A., Fleischman, A. J., \& Roy, S. (2005). Characterization of polydimethylsiloxane (PDMS) properties for biomedical micro/nanosystems. Biomedical Microdevices, 7(4), 281-293. doi: https://doi.org/10.1007/s10544-005-6070 $-2$

7. Sheen-Ophir, S., Rosner, M., \& Rubowitz, A. (2018). Feasibility of using experimental high viscosity silicone oils: A pilot study. International Journal of Retina and Vitreous, 4(1), 1-5. doi: https://doi.org/10.1186/s40942-017-0105 $\underline{-8}$

8. Callister, William D. 2007. Materials Science and Engineering. New York: John Wiley \& Sons, Inc.

9. Stanford, M. J., \& Dove, A. P. (2010). Stereocontrolled ring-opening polymerisation of lactide. Chemical Society Reviews, 39(2), 486-494. doi: https:// doi.org/10.1039/b815104k

10. Zechel, D. L., Hultzsch, K. C., Rulkens, R., Balaishis, D., Ni, Y., Pudelski, J. K.,
Lough, A. J., Manners, I., \& Foucher, D. A. (1996). Thermal and transitionmetal-catalyzed ring-opening polymerization (ROP) of [1] silaferrocenophanes with chlorine substituents at silicon: A route to tunable poly(ferrocenylsilanes). Organometallics, 15(8), 1972-1978. doi: https://doi.org/10.1021/om950911v

11. Tanabe, M., \& Manners, I. (2004). Photolytic living anionic ringopening polymerization (ROP) of silicon-bridged [1]ferrocenophanes via an iron-cyclopentadienyl bond cleavage mechanism. Journal of the American Chemical Society, 126(37), 11434-11435. doi: https:// doi.org/10.1021/ja046657s

12. Honeyman, C. H., Foucher, D. A., Dahmen, F. Y., Rulkens, R., Lough, A. J., \& Manners, I. (1995). Thermal Ring-Opening Polymerization (ROP) of Strained, Ring-Tilted, PhosphorusBridged [1]Ferrocenophanes: Synthesis of Poly(ferrocenylphosphines) and Poly(ferrocenylphosphine sulfides). Organometallics, 14(12), 5503 -5512. doi: https://doi.org/10.1021/ om00012a017

13. Giordano, G. G., \& Refojo, M. F. (1998). Silicone oils as vitreous substitutes. In Progress in Polymer Science (Oxford), 23(3), 509-532. doi: https://doi.org/10.1016/S0079-6700 (97)00046-4

14. Setiadji, S., Fitrilawati, Fauza, A. N., 
Ardi, A., Novianti, R. M., Syakir, N., Waslaluddin, Rahayu, I., Kartasasmita, A. S., \& Risdiana. (2019). Optimization of polydimethylsiloxane synthesized parameters as vitreous humour substitutes. Materials Science Forum, $966 \mathrm{MSF}, \quad$ 189-193. https:// doi.org/10.4028/www.scientific.net/ MSF.966.189

15. Handayani, P. A. (2010). Polimerisasi Akrilamid Dengan Metode Mixed-. 8, 69-78.

16. Roberts, C., Graham, A., Nemer, M., Phinney, L., Garcia, R., \& Stirrup, E. (2017). Physical Properties of LowMolecular Weight Polydimethylsiloxane Fluids. Http://Prod.Sandia.Gov/ Techlib/Access-

Control.Cgi/2017/171242.Pdf, February. http://prod.sandia.gov/

17. Liang, M. C., Vora, R. A., Duker, J. S., \& Spaide, R. F. (2013). Diagnostic and therapeutic challenges. Retina, 33(7), 1471-1474. https://doi.org/10.1097/ IAE.0b013e $318285 \mathrm{ce} 03$

18. Fitrilawati, Fauza, A. N., Ardi, A., Novianti, R. M., Syakir, N., Kartasasmita, A. S., \& Risdiana. (2018). Effect of $\mathrm{KOH}$ concentration on characteristics of polydimethylsiloxane synthesized by ring opening polymerization method. Journal of Physics: Conference Series, 1080(1). https://doi.org/10.1088/17426596/1080/1/012016
20. Barca, F., Caporossi, T., \& Rizzo, S. (2014). Silicone oil: Different physical proprieties and clinical applications. BioMed Research International, 2014, $7 . \quad$ https:// doi.org/10.1155/2014/502143

21. González-Rivera, J., Iglio, R., Barillaro, G., Duce, C., \& Tinè, M. R. (2018). Structural and thermoanalytical characterization of $3 \mathrm{D}$ porous PDMS foam materials: The effect of impurities derived from a sugar templating process. Polymers, 8(6), 113. https://doi.org/10.3390/ polym 10060616 